Article

\title{
In Vitro Anthelminthic Efficacy of Aqueous Pomegranate (Punica granatum L.) Extracts against Gastrointestinal Nematodes of Sheep
}

\author{
Fabio Castagna ${ }^{1, *}$, Domenico Britti ${ }^{1}{ }^{10}$, Manuela Oliverio ${ }^{1}\left(\mathbb{D}\right.$, Antonio Bosco $^{2}$, Sonia Bonacci ${ }^{1}$, \\ Giuseppe Iriti ${ }^{1}$, Monica Ragusa ${ }^{3}{ }^{-}$, Vincenzo Musolino ${ }^{1, *}$, Laura Rinaldi ${ }^{2}$, Ernesto Palma ${ }^{1,+}+\mathbb{C}$ \\ and Vincenzo Musella ${ }^{1,+}$ \\ 1 Department of Health Sciences, University of Catanzaro “Magna Græcia”, CISVetSUA, \\ 88100 Catanzaro, Italy; britti@unicz.it (D.B.); m.oliverio@unicz.it (M.O.); s.bonacci@unicz.it (S.B.); \\ giuseppeiriti94@gmail.com (G.I.); palma@unicz.it (E.P.); musella@unicz.it (V.M.) \\ 2 Department of Veterinary Medicine and Animal Productions, University of Naples Federico II, \\ 80137 Napoli, Italy; boscoant@tiscali.it (A.B.); lrinaldi@unina.it (L.R.) \\ 3 Department of Experimental and Clinical Medicine, University of Catanzaro Magna Græcia, CISVetSUA, \\ 88100 Catanzaro, Italy; m.ragusa@unicz.it \\ * Correspondence: fabiocastagna@unicz.it (F.C.); v.musolino@unicz.it (V.M.) \\ + These authors equally contributed in this work.
}

Received: 12 November 2020; Accepted: 16 December 2020; Published: 18 December 2020

\begin{abstract}
The worldwide increased difficulty to counteract gastrointestinal nematode (GIN) infection in sheep, due to progressing anthelmintic resistance, has led to the evaluation of other alternative helminth control options, mainly from plants. The anthelmintic efficacy of an aqueous Punica granatum macerate was evaluated in sheep naturally infected by GIN in southern Italy. The macerate was chemically characterized by chromatographic analysis coupled with high-resolution mass spectrometry (LC/HRMS) and an aliquot was concentrated to obtain a dry extract. A part was characterized, the remaining washed with methanol to obtain an insoluble residue and methanol phase. In the methanol fraction, the quantitatively predominant gallic acid was purified to obtain the pure molecule. The three fractions thus obtained were used for in vitro studies (i.e., egg hatch test) to verify anthelmintic efficacy. For this purpose, fecal samples were collected from sheep naturally infected by GINs. Fractions were diluted in $\mathrm{H}_{2} \mathrm{O} / \mathrm{DMSO} 0.5 \%$ at $1.00,0.5,0.25,0.125,0.05$, and $0.005 \mathrm{mg} / \mathrm{mL}$ concentrations. Thiabendazole $(0.25$ and $0.5 \mathrm{mg} / \mathrm{mL})$ and deionized water were used as positive and negative controls, respectively. Egg hatch test results indicated that all fractions caused a significant $(p<0.05)$ egg hatch inhibition within $48 \mathrm{~h}$ of exposure highlighting a high $(>82 \%)$ efficacy in vitro at all tested doses. Maximal egg hatching inhibition effect was exhibited by the methanol fraction $(99.3 \%$ and $89.3 \%$ at 1 and $0.005 \mathrm{mg} / \mathrm{mL}$ concentrations), followed by the insoluble residue and gallic acid $(94.7 \%$ and $85.3 \%$ and $94.0 \%$ and $82.7 \%$ at 1 and $0.005 \mathrm{mg} / \mathrm{mL}$, respectively). The current study validated the anthelmintic potential of traditional P. granatum macerate against GIN infection in sheep, thus highlighting the role of gallic acid as principal component and justifying a need to undertake further in vivo studies on these ethno-veterinary remedies.
\end{abstract}

Keywords: gastrointestinal nematodes; sheep; aqueous Punica granatum macerate; plant extracts; anthelmintic efficacy; chemical characterization; chromatographic analysis

\section{Introduction}

Infections with parasites continues to represent a serious challenge to health, welfare, productivity, and reproduction of grazing ruminants throughout the world [1]. Helminths infect livestock and cause 
the most significant losses to food production globally [2]. In particular, gastrointestinal nematode (GIN) infection, caused by different genera of nematodes (e.g., Teladorsagia, Haemonchus, Trichostrongylus, and Oesophagostomum) remains one of the main constraints to small ruminant production in southern Italy [3].

Since the mid-1960s, GIN control in livestock has heavily relied on anthelmintics. At the time of first registration, all anthelmintics used in livestock were very effective, typically reducing susceptible worm burdens by up to $99 \%$ [4]. Currently, their control is still primarily relied on the use of chemical anthelmintic drugs [5] and the availability of highly efficacious anthelmintic drugs has significantly contributed to reducing the economic burden of GIN infections [6,7]. However, after years of intensive use to optimize animal productivity, the widespread appearance of resistant parasites was inevitable [8]. Anthelmintic resistance (AR) has become a major and growing problem on small ruminant farms in many countries, EU included [9].

The maintenance of anthelmintic efficacy is important to ensure high levels of production and animal welfare [10] and the expanding development and diffusion of AR in nematode populations imposes the need to explore and validate novel solutions (or to re-discover old knowledge) for a more sustainable control of GIN in ruminants [5]. All the above has provided an impetus for the research aimed at the development of alternative control methods [11]. In many countries of the world, in particular in Asia and Africa [12-14] and in some European countries [15], plants have been used in local traditions for parasite control in small ruminants. These traditions have survived in some area of Italy [16,17], in particular in southern regions [18,19], where some aqueous plant-based macerates, including pomegranate (Punica granatum L.), are used by several farmers and pastoralists.

P. granatum plant is native in Asian countries and it has been cultivated and naturalized over the whole Mediterranean region since ancient times. This botanical species has been the subject of study as a medicinal agent with wide variety therapeutic indications [20] because different parts, such as bark, leaves, fruits and fruit rind, have medicinal significance [21]. For these reasons $P$. granatum has been used in various region in traditional medicine as a treatment for many diseases, such as repellent against medically important mosquito vectors, parasitic worm infections, and against protozoan parasites infections [22-24]. The anthelmintic activity of pomegranate is well known by the literature [25-28]. This activity seems to be mainly due to the pelletierine, a molecule belonging to the class of the alkaloids, present in the bark of the root of P. granatum [29,30]. However, pomegranate extracts are phyto-complexes characterized by a wide range of different compounds. Thus, the aims of the present study were to evaluate the in vitro anthelmintic efficacy of an aqueous $P$. granatum macerate against GINs of sheep in the Calabria region of southern Italy and to identify other molecules of $P$. granatum with anthelmintic action.

\section{Results}

\subsection{Chemical Characterization}

As preliminary study, different extraction techniques and solvents were used to usefully fractionate the aqueous pomegranate macerate. Each test was performed on $5 \mathrm{~mL}$ of aqueous macerate, corresponding to $\approx 300 \mathrm{mg}$ of dry extract. The obtained fractions were qualitatively compared by TLC (eluent phase DCM/MeOH v/v 8:2) Firstly, apolar organic solvents, such as DCM and AcOEt, were used in a liquid/liquid extraction (LLE). While DCM LLE was quite ineffective, AcOEt led to the recovery of $10 \% w / w$ fraction. In addition, washing and filtration of dried extract was performed using both $\mathrm{EtOH}$ and $\mathrm{MeOH}$. Each washing resulted in a qualitatively similar fraction respect to the AcOEt LLE extraction, but with a recovery efficiency of $30 \% w / w$ for $\mathrm{EtOH}$ and $70 \% w / w$ for $\mathrm{MeOH}$, respectively. Consequently, the macerate was fractionated, as described in the experimental part, according to the solubility in methanol. Before fractionation, the ethanol amount present in the aqueous macerate was quantified as $2.994 \mathrm{mg} / \mathrm{mL}$. The two obtained fractions, namely, the methanol fraction A and the insoluble residue $\mathrm{B}$, were analyzed by LC-HRMS and compared with the aqueous macerate. 
The chromatographic characterization of the whole macerate is showed in Figure 1. The analogues LC/HRMS analysis for the three fraction A, and B are reported in Supplementary Materials.

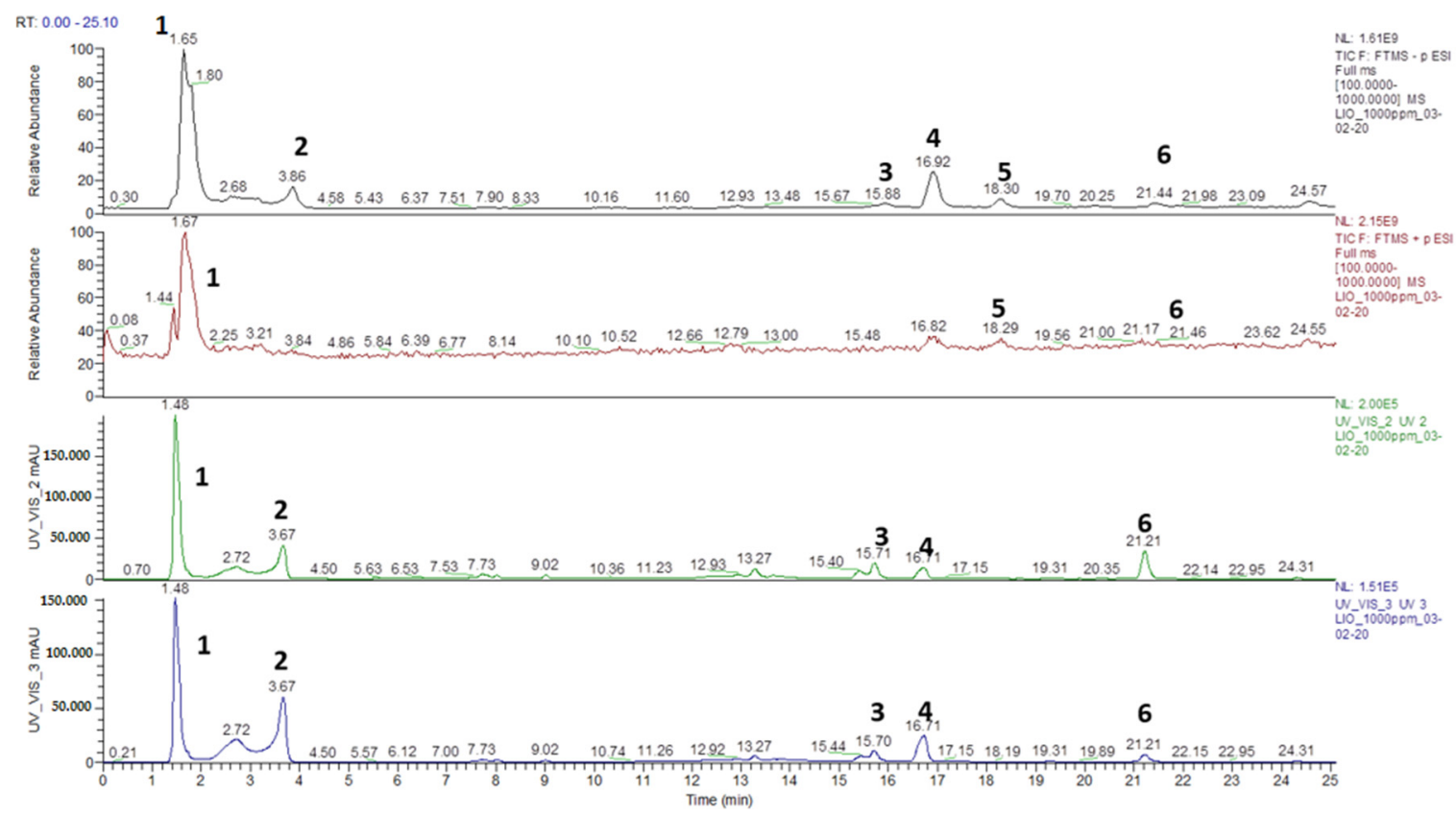

Figure 1. Full scan LC-HRMS analysis of the total dry extract, as registered in ESI(-), ESI(+) UV/VIS (240 nm) e UV/VIS (280 nm) detection modes, respectively.

It is clear that the ESI(-) ionization mode provides the widest number of information on the chemical composition of the mixture. Mass spectra are complementary to UV/VIS analyses. The chromatogram can be divided into two distinct regions according to the retention times (r.t.).

The first region, with r.t. between 0 and min, is composed by the molecules not strongly retained by the stationary phase, such as simple and complex sugars (compounds 1, 2, Figure 1).

The second region between 15 and 25 min r.t. was populated by the characteristic peaks of phenolic acids and elagiotannins (compounds 3, 4, 5 and 6, Figure 1). For each representative peak shown in Figure 1, MS/MS ESI analysis was performed in order to achieve their full identification. The characterization, with the $m / z$ values (obtained for LC/HRMS, ESI(-)) of each component together with their structural identification, is shown in Table 1.

Table 1. Chemical characterization results of total dry extract.

\begin{tabular}{ccccc}
\hline Peak LC-MS & $m / z$ Theoretical & $m / z$ Measured & Molecular Formula & Analyte \\
\hline & 149.0092 & 149.0081 & $\mathrm{C}_{4} \mathrm{H}_{5} \mathrm{O}_{6}$ & Tartaric acid \\
$(1)$ & 181.0718 & 181.0711 & $\mathrm{C}_{6} \mathrm{H}_{13} \mathrm{O}_{6}$ & $\begin{array}{c}\text { Mannitol } \\
\text { Glucuronic acid }\end{array}$ \\
& 193.0354 & 193.0347 & $\mathrm{C}_{9} \mathrm{H}_{9} \mathrm{O}_{7}$ & 2,3 -(S)-hexahydroxyphenyl- \\
& 481.0697 & 481.0626 & $\mathrm{C}_{20} \mathrm{H}_{17} \mathrm{O}_{14}$ & D-glucose \\
\hline$(2)$ & 169.0142 & 169.0134 & $\mathrm{C}_{7} \mathrm{H}_{5} \mathrm{O}_{5}$ & Gallic acid \\
\hline \multirow{2}{*}{$(3)$} & 288.9990 & 288.9992 & $\mathrm{C}_{13} \mathrm{H}_{5} \mathrm{O}_{8}$ & Phelligridin J \\
& 469.0049 & 469.0050 & $\mathrm{C}_{21} \mathrm{H}_{9} \mathrm{O}_{13}$ & Valoneic acid dilattone \\
\hline$(4)$ & 197.0455 & 197.0449 & $\mathrm{C}_{9} \mathrm{H}_{9} \mathrm{O}_{5}$ & Syringic acid \\
$(5)$ & - & 186.1129 & $\mathrm{C}_{13} \mathrm{H}_{14} \mathrm{O}$ & unknown \\
\hline \multirow{2}{*}{$(6)$} & 300.9990 & 300.9991 & $\mathrm{C}_{14} \mathrm{H}_{5} \mathrm{O}_{8}$ & Ellagic acid \\
& 447.0642 & 447.0573 & $\mathrm{C}_{20} \mathrm{H}_{15} \mathrm{O}_{12}$ & Ducheside A \\
\hline
\end{tabular}

The peak identified as (1) is a mixture of tartaric acid, glucuronic acid, mannitol, and a small percentage of an elagitannin complex (2,3-(S)-hexahydroxyphenyl-D-glucose). 
The same peak was found, as unique component, in the chromatogram of the insoluble residue fraction B (See Supplementary Materials). As fraction B represents the 30\% $w / w$ of the dry extract, it can be concluded that the extract is composed for the $30 \% w / w$ of a mixture of simple organic acids and sugars.

The peak identified as (2) in Figure 1 represented the main component in the methanol fraction A (See Supplementary Materials). It was isolated, quantified respect to the total dry extract, and characterized by ESI(-)-HRMS and ${ }^{1} \mathrm{H}-\mathrm{NMR}$. Figure 2 shows its HRMS/MS/MS spectrum, which unequivocally identifies gallic acid. The comparison with the HRMS/MS spectrum of a reference standard confirmed the structural hypothesis. Therefore, it has been observed that the dry extract is composed of about $10 \% w / w$ by gallic acid.

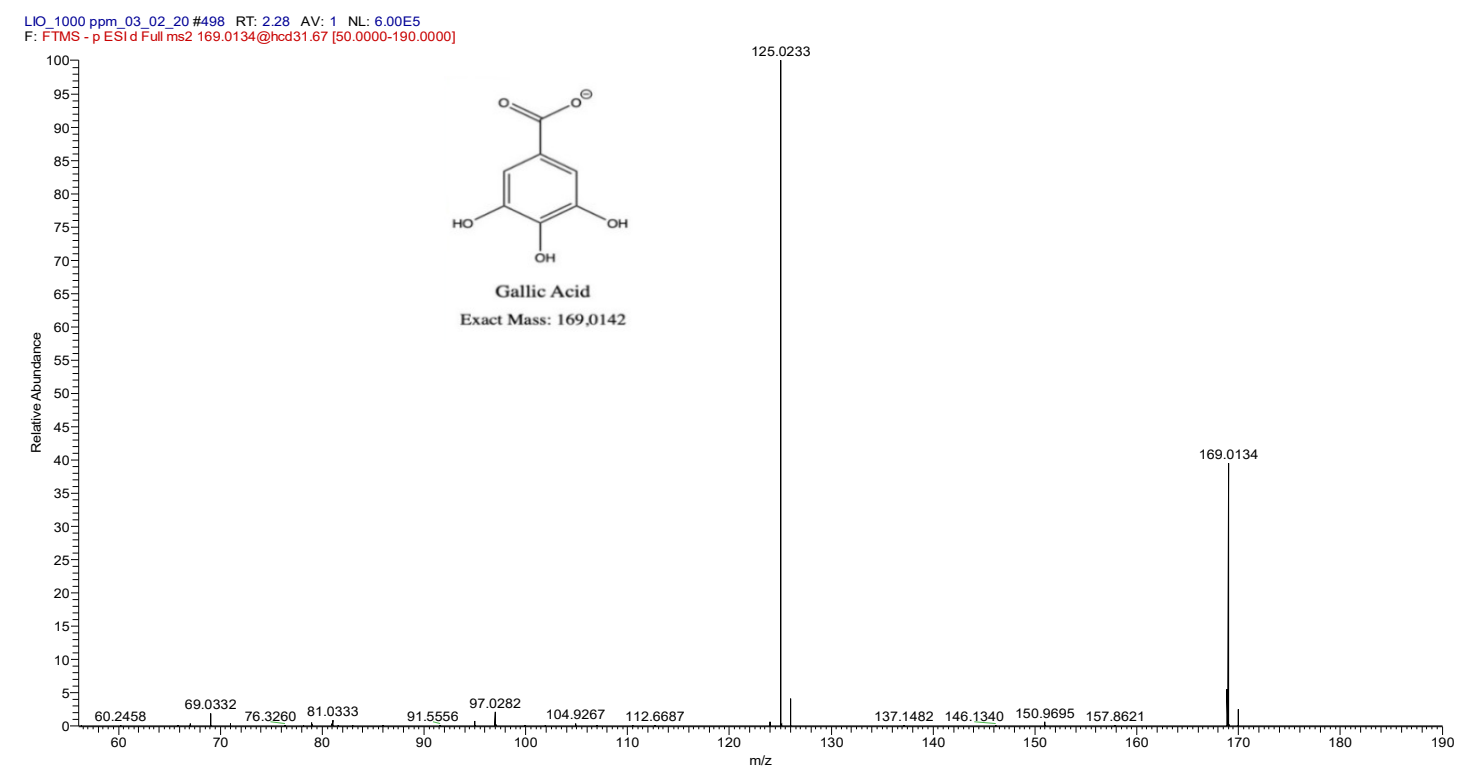

Figure 2. HRMS/MS/MS spectrum of gallic acid C, registered in ESI(-) ionization mode.

The remaining part of chromatogram was composed by two elagiotanninic derivatives valoneic acid and felligridine J (peak 3, Figure 1), siringic acid (peak 4, Figure 1), ellagic acid, and ducheside A (peak 6, Figure 1) and an unknown molecule corresponding to peak 5. All these components composed, together with gallic acid C, the methanol fraction A (see Supplementary Materials). Overall, the mixture of these components represents $60 \% w / w$ of the dry extract. Pelletierine was not found in any fractions nor in the dry extract.

\subsection{Parasitological Studies}

\subsubsection{Coprocultures}

The genera of nematodes present were: Trichostrongylus spp. (43\%), followed by Haemonchus contortus (23\%), Teladorsagia spp. (21\%), Chabertia ovina (7\%), and Cooperia spp. (6\%).

\subsubsection{Egg Hatch Test}

EHT efficacy profile of P. granatum fractions, as percentage of eggs unhatched (mean of triplicates), the positive control (TBZ) and negative control (deionized water/DMSO 0.5\%) are shown in Table 2. 
Table 2. Percentage of eggs unhatched (mean of triplicates) and Standard Deviation (SD) after treatment at various concentrations with pomegranate macerate fractions: methanol (A), insoluble residue (B), gallic acid (C), thiobendazole (TBZ) and deionized water/DMSO 0.5\%.

\begin{tabular}{cccccc}
\hline $\begin{array}{c}\text { Concentration } \\
(\mathbf{m g} / \mathrm{mL})\end{array}$ & Methanol A & Insoluble Residue B & Gallic Acid C & $\begin{array}{c}\text { TBZ (Positive } \\
\text { Control) }\end{array}$ & $\begin{array}{c}\text { Deionized } \\
\text { Water/DMSO 0.5\% } \\
\text { (Negative Control) }\end{array}$ \\
\hline $0.005 \mathrm{mg} / \mathrm{mL}$ & $89.3 \pm 2.5^{\mathrm{a} *}$ & $85.3 \pm 1.5^{\mathrm{b}}$ & $82.7 \pm 2.1^{\mathrm{b}}$ & & \\
$0.05 \mathrm{mg} / \mathrm{mL}$ & $94.0 \pm 2.6^{\mathrm{a}}$ & $89.7 \pm 1.5^{\mathrm{b}}$ & $86.3 \pm 1.1^{\mathrm{b}}$ & & \\
$0.125 \mathrm{mg} / \mathrm{mL}$ & $96.0 \pm 3.0^{\mathrm{a}}$ & $90.7 \pm 2.1^{\mathrm{b}}$ & $90.7 \pm 0.6^{\mathrm{b}}$ & & \\
$0.25 \mathrm{mg} / \mathrm{mL}$ & $97.7 \pm 1.5^{\mathrm{a}}$ & $93.3 \pm 4.2^{\mathrm{b}}$ & $91.3 \pm 1.5^{\mathrm{b}}$ & $96.7^{\mathrm{a}} \pm 1.2$ & \\
$0.5 \mathrm{mg} / \mathrm{mL}$ & $98.0 \pm 1.0^{\mathrm{a}}$ & $94.3 \pm 3.5^{\mathrm{b}}$ & $93.0 \pm 1.0^{\mathrm{b}}$ & $99.3^{\mathrm{a}} \pm 0.6$ & \\
$1 \mathrm{mg} / \mathrm{mL}$ & $99.3 \pm 0.6^{\mathrm{a}}$ & $94.7 \pm 3.8^{\mathrm{b}}$ & $94.0 \pm 2.0^{\mathrm{b}}$ & \\
\hline \multicolumn{7}{c}{${ }^{*}$ different letters highlight statistical differences between $\operatorname{groups}^{\mathrm{a}, \mathrm{b}}(p<0.05)^{\mathrm{c}}(p<0.001)}$.
\end{tabular}

The results showed $6.7 \%$ of eggs in the negative control (deionized water), $96.7 \%$ of eggs in the first positive control ( $0.25 \mathrm{mg} / \mathrm{mL}$ of TBZ), and a $99.3 \%$ of eggs in the second positive control $(0.5 \mathrm{mg} / \mathrm{mL}$ of TBZ). As regards the results of the groups with methanol (A), insoluble residue (B), and gallic acid $(C)$ at all concentrations, percentages of $>82 \%$, significantly higher $(p<0.001)$ than the positive control, have been obtained The results also showed that at each concentration, group A always had a percentage of unhatched eggs higher than group B and C $(p<0.005)$.

$\mathrm{PH}$ analysis for all fractions did not show any change in variation of acidity or basicity. The measured $\mathrm{pH}$ did not deviate from neutrality, showing a range between 6.9 and 7.1.

\section{Discussion}

Anthelmintic resistance in ruminants is a severe and worsening problem worldwide and its development is a natural evolutionary process that is difficult to prevent if anthelmintics are overused/misused in the farm [31]. This phenomenon and risks associated with the presence of anthelmintic drug residues in environment and animal origin foods, have encouraged the search for alternative molecules from plants [32]. An additional constraint in the anthelmintic use in livestock comes from the consumer and the growing demand for food drug-free products $[33,34]$. In this contest, the consumers consider the respect for the environment an essential principle of breeding and often choose products carefully from animals raised with natural systems without the use of drugs [35]. Therefore, further researches are needed to reduce the use of anthelmintics through the development of alternative approaches [36]. Several studies showed the potential of plants rich in tannin on nematodes control $[37,38]$ and, in particular, some in vitro studies highlight the inhibition of tannins contained in plants on the hatching of GIN eggs [39]. Tannins have also been shown to interfere with oxidative coupled phosphorylation and block ATP synthesis in Haemonchus contortus [40].

The anthelmintic efficacy of plant-based alkaloids was confirmed by Wang et al. (2010) [41]. Moreover, in vitro studies report that these compounds, contained in P. granatum, have antiprotozoal [42, 43], anticestoda, and antinematoda properties in various species [44], including humans [45]. An improvement in histopathological picture of the jejunum, as well as the antioxidant status protects the host tissue from injuries induced by parasites was also highlighted [38]. These properties should be ascribed mainly to phenolic compounds [46,47].

In the current study all fractions produced a significant ovicidal activity against sheep GINs at the all concentrations tested in vitro. The exhibited ovicidal effectiveness is comparable with the TBZ drug. These findings are in line with the in vitro and in vivo studies done by Hassan et al. (2020) [28] and Anjos et al. (2016) [48] that confirmed the efficacy of the P. granatum extract against Haemonchus contortus in goats and Haemonchus spp. and Cooperia spp. in cattle, respectively. The ovicidal activities $(<82 \%)$ detected in our study were higher than those reported in vitro by Aliyi et al. (2020) that reported moderate anthelmintic activity of $P$. granatum at the lowest concentrations against GIN in sheep (49.33 at $0.1 \mathrm{mg} / \mathrm{mL}, 60.67$ at $0.25 \mathrm{mg} / \mathrm{mL}$, and 72.67 at $0.5 \mathrm{mg} / \mathrm{mL}$ concentration) [27]. However, in their study Aliyi et al. (2020) [27] had used only peels crude extract of the pomegranate, while 
the aqueous macerate used in this study was a phytocomplex obtained from fruits and fruit rind. The exhibited anthelmintic effect might be attributed to the synergistic action of the components highlighted with chemical characterization. In particular, a synergistic effect due to the presence of different tannin-derivatives and phenolic acids was certainly present in the A fraction. Regarding the $B$ fraction, a significant contribution of tartaric acid and ellagitannin to this activity can be assumed, while the activity of the $C$ fraction as a pure molecule is quite surprising. This study validated the anthelmintic potential of traditional P. granatum macerate against GIN in naturally infected sheep, thus disclosing the role of gallic acid as principal component and justifies a need to undertake further in vivo studies on this macerate, because the concentrations of active substances used in vitro do not always correspond to in vivo bioavailability.

\section{Materials and Methods}

\subsection{Aqueous Macerate Preparation}

Aqueous pomegranate (Punica granatum) macerate used for this study was a traditional mixture used in the Calabria region of southern Italy against GINs of sheep.

This macerate was prepared by a Calabrian elderly breeder by macerating ripe pomegranates (fruits and fruit rind) in spring water for at least 10 months. After this time the mixture was filtered with a cloth and was ready for its use. This preparation was carried out according to ancient ethno-veterinary recipes handed down for centuries from generation to generation.

\subsection{Chemical Characterization}

The macerate was fractionated and each fraction was analyzed using the LC/MS-ESI. A $75 \mathrm{~mL}$ aliquot of pomegranate macerate has been concentrated in a speedvac and freeze-dried to obtain $4230 \mathrm{~g}$ of total dry extract.

A small portion of the extract $(15 \%)$ was retained for analysis, while the main part was washed on a porous septum with methanol to obtain an insoluble residue and a methanol phase. The methanol-soluble portion was evaporated under reduced pressure to achieve $2.61 \mathrm{~g}$ of dry fraction $(\mathrm{A}, 70 \% w / w)$; the insoluble residue was dried using a vacuum-evaporator and weighed to obtain $0.90 \mathrm{mg}(\mathrm{B}, 30 \mathrm{w} / \mathrm{w})$. The methanol fraction, analyzed by TLC (thin layer chromatography), appeared as a complex mixture of components, one of which was quantitatively predominant. The mixture was then further purified by flash chromatography (eluent phase dichloromethane/methanol 8:2) to separate the main component, obtaining $330 \mathrm{mg}$ of a pure molecule (gallic acid) (13\% of the methanol extract, about $10 \%$ of the total dry extract). All obtained fractions were then characterized by LC/HRMS in order to identify their components. The pure molecule was identified by direct infusion ESI-HRMS, then compared with a reference standard, while ${ }^{1} \mathrm{H}-\mathrm{NMR}$ spectrum was compared to the one reported in the literature (from spectral Database for Organic compounds SDBS).

Chromatography was performed using a Thermo Scientific (Rodano, MI, Italy) Dionex Ultimate 3000 RS, injecting directly into a Thermo Scientific Hypersil Gold C18 column $(50 \times 2.1 \mathrm{~mm}, 1.9 \mu \mathrm{m}$ particle size), equilibrated in $95 \%$ solvent $\mathrm{A}(0.1 \%$ aqueous solution of formic acid) and in $5 \%$ solvent $\mathrm{B}$ (methanol). The column and autosampler temperatures were maintained at $24{ }^{\circ} \mathrm{C}$ and $20{ }^{\circ} \mathrm{C}$, respectively. The elution flow rate was $200 \mu \mathrm{L} / \mathrm{min}$, the column was equilibrated for 2 min with $5 \%$ solvent B, after increasing solvent B concentration from 5 to $100 \%$ in $45 \mathrm{~min}$, remain for $2 \mathrm{~min}$ in isocratic conditions and then decreasing solvent B from $100 \%$ to $5 \%$ in $8 \mathrm{~min}$ and remain for other $3 \mathrm{~min}$ in isocratic conditions. The total run time, including column wash and equilibration was $60 \mathrm{~min}$. For High Resolution Mass Spectrometry (HRMS) a Thermo Scientific Q-Exactive ${ }^{\mathrm{TM}}$ (Rodano, MI, Italy) mass spectrometer was operated using electrospray with both negative and positive polarities, at 70,000 resolving power (defined as FWHM at $m / z 200$ ), IT $100 \mathrm{~ms}$, and ACG target $=3 \times 10^{6}$, by full scan analysis (mass range 100 to $1000 \mathrm{amu}$ ). Source conditions were spray voltage $3.0 \mathrm{KV}$, sheath gas: 20, arbitrary units, Auxiliary gas: 8 , probe heater temperature: $280^{\circ} \mathrm{C}$; capillary temperature: 
$320^{\circ} \mathrm{C}$; S-Lens RF Level: 50 . Prior to the beginning of the analysis, the instrument was daily calibrated by "Thermo ESI negative ion calibration solution" containing sodium dodecylsulfate $(\mathrm{m} / \mathrm{z} 265.145)$, sodium taurocholate $(\mathrm{m} / \mathrm{z}$ 514.278) and Ultramark 1621 ( $\mathrm{m} / \mathrm{z}$ : 1279.982, 1379.974, 1479.967, 1579.958, $1679.952,1769.990)$. Moreover, a daily analysis of a standard reference solution of gallic acid $(50 \mathrm{mg} / \mathrm{L})$ was performed in order to assess the LC-HRMS method stability.

Quantification of ethanol in the macerate was performed through head-space gas chromatography on a GC-Trace 1310 Thermo Scientific equipped with a TG-624 $(30 \mathrm{~m} \times 0.32 \mathrm{~mm} \times 0.18 \mu \mathrm{m})$ and a flame ionization detector (FID). The samples were injected via a Triplus RSH Head-space system with a $1 \mathrm{~mL}$ standard injection valve.

Chromeleon software was used for the operation of the chromatograph and acquisition and processing of data. The GC system was supplied with $\mathrm{H} 2(35 \mathrm{~mL} / \mathrm{min})$ from a NM-H2-500 generator (Thermo Scientific), Air (flow rate $350 \mathrm{~mL} / \mathrm{min}$ ), and N2 (5 mL/min).

The head-space was set to $80^{\circ} \mathrm{C}$ for $5 \mathrm{~min}$, then the sample was transferred to the GC system. The GC inlet and syringe were heated to $150{ }^{\circ} \mathrm{C}$ and $100{ }^{\circ} \mathrm{C}$, respectively. The gas chromatography system was operated under the following conditions: oven temperature at $40^{\circ} \mathrm{C}$ for 6 min and then heated to $140{ }^{\circ} \mathrm{C}$, heating rate $20^{\circ} \mathrm{C} / \mathrm{min}$; detector temperature $180^{\circ} \mathrm{C}$.

\subsection{Parasitological Study}

\subsubsection{Recovery of GIN Eggs}

GIN eggs were recovered from samples collected directly from the rectal ampulla of naturally infected sheep in a farm located in southern Italy. The fecal samples were processed within $2 \mathrm{~h}$ of collection by using the egg recovery technique as described by Coles et al. (1992) [49] and Bosco et al. (2020) [36].

Firstly, fecal samples were homogenized and filtered under running water through sieves with a mesh size of 125, 63, and $38 \mu \mathrm{m}$ in order to separate the eggs from the feces. Next, the GIN eggs retained on the last sieve were washed and centrifuged for $3 \mathrm{~min}$ at $170 \times g$ with distilled water, after which the supernatant was discarded. In the end, centrifugation was performed using $40 \%$ sugar solution to float the eggs which are then isolated in new tubes, mixed with distilled water and then centrifuged two more times in order to remove pellets and to get aqueous solution with eggs.

Eggs were examined microscopically to record if embryonation had not begun. Ten aliquots of $0.1 \mathrm{~mL}$ were taken, and the number of eggs counted [50]. The mean number of eggs counted in these aliquots was 150 per $0.1 \mathrm{~mL}$ of egg suspension.

\subsubsection{Coprocultures}

In order to identify the GIN genera, larval cultures were performed, following the protocol described by the Ministry of Agriculture, Fisheries, and Food [51]. Developed third-stage larvae (L3) were identified using the morphological keys proposed by van Wyk and Mayhew (2013) [52]. Identification and percentages of each nematode genera were conducted on $100 \mathrm{~L} 3$; if a sample had 100 or less L3 present, all larvae were identified. Thus, on the total number of larvae identified, it was possible to give the percentage of each genus.

\subsubsection{Anthelmintic Efficacy}

Egg hatch test (EHT) was performed to evaluate the in vitro anthelmintic efficacy of the three fractions. The EHT procedure followed that recommended by the World Association for the Advancement of Veterinary Parasitology (WAAVP) [49]. Each fraction (A, B and C) was analyzed by three replicates and tested at different concentrations compared to the negative control (deionized water/0.5\% DMSO without anthelmintic) and the positive controls (thiabendazole).

The protocol to prepare thiabendazole (TBZ, Sigma, Saint Louis, MO, USA) solution used deionized water with a neutral $\mathrm{pH}$. 
A stock solution of thiabendazole was prepared by dissolving the pure compound in dimethyl sulfoxide (DMSO), subsequent dilutions were made in deionized water with a neutral $\mathrm{pH}$, and following the protocol described by Von Samson-Himmelstjerna et al. (2009) [53].

The final concentrations in the EHT were prepared by adding $10 \mu \mathrm{L}$ of each TBZ solution into $1.99 \mathrm{~mL}$ of a suspension with approximately $150 \mathrm{eggs} / \mathrm{mL}$ in water. The final TBZ concentrations used in this study were 0.2 and $0.5 \mathrm{mg} / \mathrm{mL}$.

The $\mathrm{A}, \mathrm{B}$, and $\mathrm{C}$ fractions were diluted in deionized water $/ \mathrm{DMSO} 0.5 \%$ at the concentrations of $1 \mathrm{mg} / \mathrm{mL}, 0.5 \mathrm{mg} / \mathrm{mL}, 0.125 \mathrm{mg} / \mathrm{mL}, 0,05 \mathrm{mg} / \mathrm{mL}$, and $0.005 \mathrm{mg} / \mathrm{mL}$ ).

The 24-well tissue culture test plates (Corning Incorporated, Life sciences, Salt Lake City, UT, USA) were incubated for $48 \mathrm{~h}$ at $25^{\circ} \mathrm{C}$. The incubation was then terminated by adding $10 \mu \mathrm{L}$ of Lugol's iodine solution to each well. After $48 \mathrm{~h}$, at least 100 eggs (dead, embryonated) and hatched first-stage larvae in each well were counted under a microscope (Leica, Wetzlar, Germany, 20x).

The $\mathrm{pH}$ of each extract was measured using a $\mathrm{pH}$ meter (Hanna instruments Hi-223 calibration check microprocessor $\mathrm{pH}$ meter). All $\mathrm{pH}$ readings were conducted on every working solution in triplicate.

\subsubsection{Statistical Analysis}

The arithmetic mean eggs per gram of feces (EPG) and standard deviation (SD) were calculated for the different A, B, and C fractions were analyzed using a one-way ANOVA with post hoc Fisher's least significant difference (LSD) for more intra-group analysis and not only between the groups. Statistical analysis was carried out using STATA v. 10.0 software (Stata Corp., Lakeway, TX, USA).

\section{Conclusions}

In southern Italy, some breeders and shepherds continue to use traditional plants mixtures to treat GIN infections in sheep and it can be asserted that some of these are effective. In particular, the significant in vitro ovicidal activity of aqueous P. granatum macerate fractions showed in the present study, highlighted the anthelmintic potential of this ethno-veterinary remedy for the control of GINs in the sheep. However, further in vivo studies are needed to confirm the obtained results and evaluate the therapeutic potential and future applicability.

Supplementary Materials: The following are available online at http://www.mdpi.com/2076-0817/9/12/1063/s1, Figure S1: Full LC-HRMS ESI(-) of methanol fraction A; Figure S2: Full LC-HRMS ESI(-) of insoluble residue fraction B; Figure S3: HRMS ESI(-) of gallic acid fraction C; Figure S4: HRMS/MS ESI(-) of gallic acid fraction C; Figure S5: Full LC-HRMS ESI(-) of peak 1; Figure S6: HRMS/MS ESI(-) of peak 1; Figure S7: Full LC-HRMS ESI(-) of peak 2; Figure S8: HRMS/MS ESI(-) of peak 2; Figure S9: Full LC-HRMS ESI(-) of peak 3; Figure S10: HRMS/MS ESI(-) of peak 3; Figure S11: Full LC-HRMS ESI(-) of peak 4; Figure S12: HRMS/MS ESI(-) of peak 4; Figure S13: Full LC-HRMS ESI(-) of peak 5; Figure S14: HRMS/MS ESI(-) of peak 5; Figure S15: Full LC-HRMS ESI(-) of peak 6; Figure S16: HRMS/MS ESI(-) of peak 6.

Author Contributions: Conceptualization, F.C., D.B., M.O., A.B., V.M. (Vincenzo Musolino), E.P., and V.M. (Vincenzo Musella); methodology, F.C., D.B., M.O., V.M. (Vincenzo Musolino), L.R., E.P., and V.M. (Vincenzo Musella); investigation (field veterinary ethnobotany researches), F.C. and V.M. (Vincenzo Musolino); laboratory analyses (chemical characterization), G.I. and S.B.; laboratory analyses (preparation and dosages of the fractions), M.R., F.C., and A.B.; laboratory analyses (parasitological studies), A.B., F.C., and M.R.; data curation, F.C., A.B., M.O., V.M. (Vincenzo Musolino), and V.M. (Vincenzo Musella); writing-original draft preparation, F.C., D.B., M.O., A.B., and V.M. (Vincenzo Musella); supervision, D.B., L.R., E.P., and V.M. (Vincenzo Musella). All authors have read and agreed to the published version of the manuscript.

Funding: This research received no external funding.

Acknowledgments: The authors would like to express sincere appreciation to COST Action COMBAR CA16230 (COMBatting Anthelmintic Resistance in Ruminants, https://www.combar-ca.eu/), to the breeder Francesco Talarico, expert of the secrets and virtues of Calabrian veterinary ethnobotany and finally to Mario Parrilla (Department of Veterinary Medicine and Animal Production, University of Naples Federico II, CREMOPAR, Naples, Italy) for his technical collaboration in CREMOPAR laboratories.

Conflicts of Interest: The authors declare no conflict of interest. 


\section{References}

1. Morgan, E.R.; Charlier, J.; Hendrickx, G.; Biggeri, A.; Catalan, D.; Von Samson-Himmelstjerna, G.; Demeler, J.; Müller, E.; Van Dijk, J.; Kenyon, F.; et al. Global Change and Helminth Infections in Grazing Ruminants in Europe: Impacts, Trends and Sustainable Solutions. Agriculture 2013, 3, 484-502. [CrossRef]

2. Mavrot, F.; Hertzberg, H.; Torgerson, P. Effect of gastro-intestinal nematode infection on sheep performance: A systematic review and meta-analysis. Parasites Vectors 2015, 8, 557. [CrossRef] [PubMed]

3. Musella, V.; Catelan, D.; Rinaldi, L.; Lagazio, C.; Cringoli, G.; Biggeri, A. Covariate selection in multivariate spatial analysis of ovine parasitic infection. Prev. Vet. Med. 2011, 99, 69-77. [CrossRef] [PubMed]

4. Coles, G.C.; Jackson, F.; Pomroy, W.E.; Prichard, R.K.; Von Samson-Himmelstjerna, G.; Silvestre, A.; Taylor, M.A.; Vercruysse, J. The detection of anthelmintic resistance in nematodes of veterinary importance. Vet. Parasitol. 2006, 136, 167-185. [CrossRef] [PubMed]

5. Hoste, H.; Torres-Acosta, J. Non chemical control of helminths in ruminants: Adapting solutions for changing worms in a changing world. Vet. Parasitol. 2011, 180, 144-154. [CrossRef] [PubMed]

6. Woods, D.J.; Knauer, C.S. Discovery of veterinary antiparasitic agents in the 21st Century: A view from industry. Int. J. Parasitol. 2010, 40, 1177-1181. [CrossRef] [PubMed]

7. Van Der Voort, M.; Charlier, J.; Lauwers, L.; Vercruysse, J.; Van Huylenbroeck, G.; Van Meensel, J. Conceptual framework for analysing farm-specific economic effects of helminth infections in ruminants and control strategies. Prev. Vet. Med. 2013, 109, 228-235. [CrossRef]

8. Lifschitz, A.; Ballent, M.; Virkel, G.; Sallovitz, J.; Viviani, P.; Lanusse, C. Accumulation of monepantel and its sulphone derivative in tissues of nematode location in sheep: Pharmacokinetic support to its excellent nematodicidal activity. Vet. Parasitol. 2014, 203, 120-126. [CrossRef]

9. Rose, H.; Rinaldi, L.; Bosco, A.; Mavrot, F.; De Waal, T.; Skuce, P.; Charlier, J.; Torgerson, P.R.; Hertzberg, H.; Hendrickx, G.; et al. Widespread anthelmintic resistance in European farmed ruminants: A systematic review. Vet. Rec. 2015, 176, 546. [CrossRef]

10. Rinaldi, L.; Morgan, E.R.; Bosco, A.; Coles, G.C.; Cringoli, G. The maintenance of anthelmintic efficacy in sheep in a Mediterranean climate. Vet. Parasitol. 2014, 203, 139-143. [CrossRef]

11. Waller, P.J.; Thamsborg, S.M. Nematode control in "green" ruminant production systems. Trends Parasitol. 2004, 20, 493-497. [CrossRef] [PubMed]

12. Bauri, R.K.; Tigga, M.N.; Kullu, S.S. A review on use of medicinal plants to control parasites. Indian J. Nat. Prod. Resour. 2015, 6, 268-277.

13. Oyserman, D.; Brickman, D.; Bybee, D.; Celious, A. Fitting in Matters. Psychol. Sci. 2006, 17, 854-861. [CrossRef] [PubMed]

14. Githiori, J.B.; Athanasiadou, S.; Thamsborg, S.M. Use of plants in novel approaches for control of gastrointestinal helminths in livestock with emphasis on small ruminants. Vet. Parasitol. 2006, 139, 308-320. [CrossRef] [PubMed]

15. Mayer, M.; Vogl, C.R.; Amorena, M.; Hamburger, M.; Walkenhorst, M. Treatment of Organic Livestock with Medicinal Plants: A Systematic Review of European Ethnoveterinary Research. Complementary Med. Res. 2014, 21, 375-386. [CrossRef] [PubMed]

16. Viegi, L.; Pieroni, A.; Guarrera, P.M.; Vangelisti, R. A review of plants used in folk veterinary medicine in Italy as basis for a databank. J. Ethnopharmacol. 2003, 89, 221-244. [CrossRef]

17. Calzetta, L.; Pistocchini, E.; Leo, A.; Roncada, P.; Ritondo, B.L.; Palma, E.; Di Cave, D.; Britti, D. Anthelminthic medicinal plants in veterinary ethnopharmacology: A network meta-analysis following the PRISMA-P and PROSPERO recommendations. Heliyon 2020, 6, e03256. [CrossRef] [PubMed]

18. Passalacqua, N.G.; De Fine, G.; Guarrera, P.M. Contribution to the knowledge of the veterinary science and of the ethnobotany in Calabria region (Southern Italy). J. Ethnobiol. Ethnomedicine 2006, 2, 52. [CrossRef]

19. Guarrera, P.M.; Lucia, L.M. Ethnobotanical remarks on Central and Southern Italy. J. Ethnobiol. Ethnomedicine 2007, 3, 23. [CrossRef]

20. Bassiri-Jahromi, S. Punica granaturn (Pomegranate) activity in health promotion and cancer prevention. Oncol. Rev. 2018, 12, 345.

21. Arun, N.; Road, R.; Pradesh, U. Punica granatum: A Review on Pharmacological and Therapeutic Properties. Int. J. Pharm. Sci. Res. 2012, 3, 1240. 
22. Baranitharan, M.; Tamizhazhagan, V.; Kovendan, K.; Senthilmurugan, S. Punica Granatum-Based Green Ethanolic Extract as Highly Effective and Eco-Friendly Larvicide, Repellent against Medically Important Mosquito Vectors. Entomol. Appl. Sci. Lett. 2019, 6, 33-41.

23. Abdel-Ghaffar, F.; Semmler, M.; Al-Rasheid, K.A.S.; Strassen, B.; Fischer, K.; Aksu, G.; Klimpel, S.; Mehlhorn, H. The effects of different plant extracts on intestinal cestodes and on trematodes. Parasitol. Res. 2010, 108,979-984. [CrossRef] [PubMed]

24. Abdel-Hafeez, E.H.; Ahmed, A.K. The Efficacy of Pomegranate (Punica granatum) Peel Extract on Experimentally Infected Rats with Blastocystis spp. J. Anc. Dis. Prev. Remedies 2016, 4. [CrossRef]

25. Mahajan, D.C.; Satyapal, U.S.; Tatke, P.A.; Naharwar, V. Antimicrobial and anthelmentic activity of Punica granatum fruit peel extracts. Int. J. Pharmacogn. Phytochem. Res. 2014, 6, 482-487.

26. Jabeen, N.; Anwar, S.; Mahmood, Q.; Zia, M.A.; Murtaza, G. In vitro anthelmintic efficacy of native plants against Haemonchus contortus. Acta Pol. Pharm. Drug Res. 2015, 72, 1051-1055.

27. Ahmed, A.H.; Ejo, M.; Feyera, T.; Regassa, D.; Mummed, B.; Assefa, S. In Vitro Anthelmintic Activity of Crude Extracts of Artemisia herba-alba and Punica granatum against Haemonchus contortus. J. Parasitol. Res. 2020, 2020, 4950196. [CrossRef]

28. Anthelmintic Potency and Curative Effect of Pomegranate Peels Ethanolic Extract against Haemonchus contortus Infection in Goats. Int. J. Vet. Sci. 2020. [CrossRef]

29. Aggarwal, R.; Kaur, K.; Suri, M.; Bagai, U. Anthelmintic potential of Calotropis procera, Azadirachta indica and Punica granatum against Gastrothylax indicus. J. Parasit. Dis. 2015, 40, 1230-1238. [CrossRef]

30. Jayaprakash, A. Punica granatum: A Review on Phytochemicals, Antioxidant and Antimicrobial. J. Acad. Ind. Res. 2017, 5, 132-138.

31. Kaplan, R.M. Biology, Epidemiology, Diagnosis, and Management of Anthelmintic Resistance in Gastrointestinal Nematodes of Livestock. Vet. Clin. N. Am. Food Anim. Pr. 2020, 36, 17-30. [CrossRef] [PubMed]

32. D'Ambola, M.; Bosco, A.; Ariano, A.; Rinaldi, L.; Bader, A.; Amadesi, A.; Cringoli, G.; Severino, L. In Vitro Anthelminthic Efficacy of Hypoestes forskaolii (Vahl) R.Br (Acanthaceae) Extracts on Gastrointestinal Nematodes of Sheep. Vet. Sci. 2018, 5, 89. [CrossRef] [PubMed]

33. Harper, G.C.; Makatouni, A. Consumer perception of organic food production and farm animal welfare. Br. Food J. 2002, 104, 287-299. [CrossRef]

34. Martelli, G. Consumers' perception of farm animal welfare: An Italian and European perspective. Ital. J. Anim. Sci. 2009, 8, 31-41. [CrossRef]

35. Castagna, F.; Palma, E.; Cringoli, G.; Bosco, A.; Nisticò, N.; Caligiuri, G.; Britti, D.; Musella, V. Use of Complementary Natural Feed for Gastrointestinal Nematodes Control in Sheep: Effectiveness and Benefits for Animals. Animals 2019, 9, 1037. [CrossRef]

36. Bosco, A.; Kießler, J.; Amadesi, A.; Várady, M.; Hinney, B.; Ianniello, D.; Maurelli, M.P.; Cringoli, G.; Rinaldi, L. The threat of reduced efficacy of anthelmintics against gastrointestinal nematodes in sheep from an area considered anthelmintic resistance-free. Parasites Vectors 2020, 13, 457. [CrossRef]

37. Min, B.; Hart, S. Tannins for suppression of internal parasites. J. Anim. Sci. 2003. [CrossRef]

38. Hoste, H.; Torres-Acosta, J.; Sandoval-Castro, C.; Mueller-Harvey, I.; Sotiraki, S.; Louvandini, H.; Thamsborg, S.; Terrill, T. Tannin containing legumes as a model for nutraceuticals against digestive parasites in livestock. Vet. Parasitol. 2015, 212, 5-17. [CrossRef]

39. Joshi, B.; Kommuru, D.; Terrill, T.; Mosjidis, J.; Burke, J.; Shakya, K.; Miller, J. Effect of feeding sericea lespedeza leaf meal in goats experimentally infected with Haemonchus contortus. Vet. Parasitol. 2011, 178, 192-197. [CrossRef]

40. Martin, R. Modes of action of anthelmintic drugs. Vet. J. 1997, 154, 11-34. [CrossRef]

41. Wang, R.; Ding, Y.; Liu, R.; Xiang, L.; Du, L. Pomegranate: Constituents, bioactivities and pharmacokinetics. Fruit Veg. Cereal Sci. Biotechnol. 2010, 4, 77-87.

42. Dell'Agli, M.; Galli, G.V.; Corbett, Y.; Taramelli, D.; Lucantoni, L.; Habluetzel, A.; Maschi, O.; Caruso, D.; Giavarini, F.; Romeo, S.; et al. Antiplasmodial activity of Punica granatum L. fruit rind. J. Ethnopharmacol. 2009, 125, 279-285. [CrossRef] [PubMed]

43. Al-Mathal, E.M.; AlSalem, A.M. Pomegranate (Punica granatum) peel is effective in a murine model of experimental Cryptosporidium paroum. Exp. Parasitol. 2012, 131, 350-357. [CrossRef] [PubMed] 
44. Tariq, K.A.; Tantry, M.A. Preliminary Studies on Plants with Anthelmintic Properties in Kashmir-The North-West Temperate Himalayan Region of India. Chin. Med. 2012, 3, 106-112. [CrossRef]

45. Yones, D.A.; Badary, D.M.; Sayed, H.M.B.; Bayoumi, S.A.H.; Khalifa, A.A.; El-Moghazy, A.M. Comparative Evaluation of Anthelmintic Activity of Edible and Ornamental Pomegranate Ethanolic Extracts against Schistosoma mansoni. BioMed Res. Int. 2016, 2016, 1-15. [CrossRef]

46. Negi, P.; Jayaprakasha, G. Antioxidant and Antibacterial Activities of Punica granatum Peel Extracts. J. Food Sci. 2003, 68, 1473-1477. [CrossRef]

47. Aviram, M.; Volkova, N.; Coleman, R.; Dreher, M.; Reddy, M.K.; Ferreira, D.; Rosenblat, M. Pomegranate phenolics from the peels, arils, and flowers are antiatherogenic: Studies in vivo in atherosclerotic apolipoprotein E-deficient (E0) mice and in vitro in cultured macrophages and lipoproteins. J. Agric. Food Chem. 2008, 56, 1148-1157. [CrossRef]

48. Dos Anjos, C.; Silva, B.T.; Fertonani, L.H.S.; Matsumoto, L.S.; De Mello-Peixoto, E.C.T.; Silva, C.S.; Da Silva, R.M.G. Pomegranate extracts on larval inhibition of Haemonchus spp and Cooperia spp obtained from cattle. Biosci. J. 2016, 32, 1277-1285. [CrossRef]

49. Coles, G.; Bauer, C.; Borgsteede, F.; Geerts, S.; Klei, T.; Taylor, M.; Waller, P. World Association for the Advancement of Veterinary Parasitology (W.A.A.V.P.) methods for the detection of anthelmintic resistance in nematodes of veterinary importance. Vet. Parasitol. 1992, 44, 35-44. [CrossRef]

50. Godber, O.F.; Phythian, C.J.; Bosco, A.; Ianniello, D.; Coles, G.; Rinaldi, L.; Cringoli, G. A comparison of the FECPAK and Mini-FLOTAC faecal egg counting techniques. Vet. Parasitol. 2015, 207, 342-345. [CrossRef]

51. Friedhoff, K. Manual of veterinary parasitological laboratory techniques. Vet. Parasitol. 1978, 4, 200-201. [CrossRef]

52. Van Wyk, J.A.; Mayhew, E. Morphological identification of parasitic nematode infective larvae of small ruminants and cattle: A practical lab guide. Onderstepoort J. Vet. Res. 2013, 80, 14. [CrossRef] [PubMed]

53. Von Samson-Himmelstjerna, G.; Coles, G.C.; Jackson, F.; Bauer, C.; Borgsteede, F.; Cirak, V.Y.; Demeler, J.; Donnan, A.; Dorny, P.; Epe, C.; et al. Standardization of the egg hatch test for the detection of benzimidazole resistance in parasitic nematodes. Parasitol. Res. 2009, 105, 825-834. [CrossRef] [PubMed]

Publisher's Note: MDPI stays neutral with regard to jurisdictional claims in published maps and institutional affiliations.

(C) 2020 by the authors. Licensee MDPI, Basel, Switzerland. This article is an open access article distributed under the terms and conditions of the Creative Commons Attribution (CC BY) license (http://creativecommons.org/licenses/by/4.0/). 